\title{
O ALUNO DE ENFERMAGEM NO CUIDADO À CRIANÇA PORTADORA DE DOENÇA CRÔNICA: RELATO DE EXPERIÊNCIA
}

Simone Renata Lunardelo*

Cursando o $7^{\circ}$ semestre de graduação em Enfermagem iniciei o processo de aprendizagem em Enfermagem Pediátrica e Neonatal. O assunto era interessante e ao mesmo tempo apavorante visto a pouca vivência com crianças no meu dia-a-dia. O ensino teórico objetivando o cuidado integral à criança mostrava-me os pressupostos da Enfermagem Pediátrica. Na minha concepção funcionava como uma fórmula: saber, habilidade técnica, carinho e conforto. O saber vinha dos estudos, das leituras; a habilidade técnica viria com o ensino clínico; o carinho e conforto surgiriam do eu íntimo e a resposta da criança a esse carinho viria do sorriso, se aceitação positiva ou do choro, se negativa.

O ensino clínico iniciou e comecei a cuidar de uma criança do sexo feminino de três anos de idade, com o diagnóstico de Insuficiência Renal Crônica que estava internada na companhia dos pais. A terapêutica era a diálise peritonial ambulatorial contínua e quando necessário devido a síndrome urêmica a criança era internada para melhor acompanhamento de seu estado pela equipe de saúde (o que é bastante freqüente).

Deparei-me com uma criança com um estado geral regular, bastante atenta, mas que dificilmente se comunica com pessoas que não são do seu ciclo familiar, não chora, não ri, não conversa, não brinca. Para mim foi muito difícil, eu não tinha "feed back" nas brincadeiras; até o dia em que fui visitá-la fora do plantão. Estava de roupa convencional, nada de branco...e como foi diferente a reação dela comigo, tudo o que idealizei estava acontecendo: seu sorriso, seu carinho. Os outros profissionais da clínica também perceberam essa "síndrome do avental branco" e esse fato inquietou-me. MADEIRA et al. (1996) relatam que a hospitalização traz inúmeros malefícios, pois o hospital é considerado um ambiente hostil para o emocional da criança e dos pais e muitas crianças freqüentemente hospitalizadas ficam conhecidas como "freguesas" nas unidades vivendo o ciclo vicioso internação - alta internação.

A situação dos pais foi outro fato marcante, descreveram-me a angústia vivenciada por eles e como repentinamente viram as coisas mudarem e a vida transformar-se rapidamente. Tentaram descobrir o porque, culparam-se, desestruturaram-se e nada de resposta. A resposta veio bem depois. Foi difícil disse a mãe. FREDERICO NETO (1992) em seu livro diz que os pais encaram a doença no clima mais pessimista; a doença alcança sentimentos de culpa, perda e angústia, além de colocá-los a todo momento a prova se estão agindo corretamente ou não. Esse último aspecto é muito relevante para a atualidade do relacionamento do casal. Em alguns momentos presenciei a vida privada da família, presenciei o agir corretamente, o agir melhor que o outro. Entre os pais da criança havia um certa disputa de quem realizava melhor as trocas das bolsas, quem realizava melhor o curativo, com quem ela dormia melhor; e assustadoramente a criança percebia essa disputa interferindo no seu estado de humor e saúde. Vendo essa situação, não pude deixar de prestar assistência também a família.

DARBYSHIRE (1994), aborda a humanização da assistência enfocando a participação e envolvimento dos pais. No entanto, esta participação muitas vezes é vista pelos enfermeiros a partir de uma perspectiva funcional e imediatista. Partindo deste pressuposto, o autor argumenta que os pais tornam-se problemas que necessitam ser resolvidos ao invés de participantes e colaboradores do cuidado da criança.

* Aluna do $8^{\circ}$ semestre de Graduação em Enfermagem da Escola de Enfermagem de Ribeirão Preto da Universidade de São Paulo 
A relação da família comigo no início foi de muita desconfiança. Houve alguns atritos entre a família e os profissionais decorrentes da assistência que vinha sendo prestada e a família tentando proteger a criança monopolizava os cuidados como banho, alimentação, curativo, troca de bolsa etc. Isso para mim foi uma frustração, pois tinha a ânsia de prestar esses cuidados. No começo me senti desfavorecida no ensino clínico, mas depois passei a compreender a complexidade da assistência de enfermagem. Transformei-me em educadora e colaboradora; educando para o cuidado domiciliar e colaborando para melhorar a situação emocional da criança e da família. Esta dimensão do processo ensino - aprendizado - cuidado é um dos princípios norteadores da disciplina Enfermagem Pediátrica e Neonatal.

Buscando um melhor entendimento do que é cuidar de uma criança portadora de doença crônica coloquei-me no lugar desses pais, dessa criança, busquei as causas e conseqüências e tentei assistí-los. Na literatura, ANGELO (1997) proporcionou-me compreender que a fase de descobrimento da doença da criança e decisões que a família deve tomar sobre o tratamento é marcada pela dor, temor e pânico. Mesmo

\section{REFERÊNCIAS BIBLIOGRÁFICAS}

01. ANGELO, M. Com a família em tempos difíceis: uma perspectiva de enfermagem. São Paulo, 1997.Tese (Livre-Docência) - Escola de Enfermagem da Universidade de São Paulo.

02. DARBYSHIRE, P. Living with a sick child in hospital: the experience of parents and nurses. London: Chapman \& Hall, 1994. com todo o sofrimento a família percebe que não pode apenas ficar sentindo medo e portanto começa a agir em benefício da criança. A família busca melhores recursos (profissionais e materiais) para se sentir mais segura. Essa "segurança" vem da ânsia de ouvir "foi engano". Inicialmente a família vivencia o desestruturamento do cotidiano familiar, ou seja, direciona-se para a melhora de um filho e as outras coisas ficam meio que perdidas. Geralmente, o pai por motivos laborais permanece em casa e quem cuida dos outros filhos é, por exemplo, a avó, a tia etc. Isso para a mãe que está hospitalizada com a criança doente é motivo de muita preocupação.

Essa experiência mostrou-me o quão interessante e rico é cuidar de uma criança portadora de doença crônica e cabe ao profissional de enfermagem estar atento às variáveis e aos acontecimentos e assim intervir nesse processo, objetivando a tão sonhada assistência integral à criança. Ao aluno de enfermagem cabe também encarar os fatos e aproveitá-los; achar as oportunidades e trabalhálas com dedicação pois é neste processo singular que nos transformaremos em enfermeiros.

\section{FREDERICO NETO, F. Pediatria ao alcance dos}

pais: compreender a doença é o melhor remédio. Rio de Janeiro: Imago, 1992.

04. MADEIRA, L.M. et al. Reinternação pediátrica: conhecendo a magnitude do problema. Revista Brasileira de Enfermagem, v.49, n.4, p.531$548,1996$. 